\title{
Enigma das Ondas
}

Rodrigo Garcia Lopes ${ }^{i}$

\section{Mendigos}

'Tis News as null as nothing,

Emily Dickinson

Na aurora putrefata

mendigos pescam imagens,

imagens de mendigos,

clichês batidos

(disfarce: preconceito de classe)

nas caçambas e latas de lixo

vazias de signos.

Oh, masters of the universe,

o lindo petróleo que jorra

da flor indiferente e idiota.

Mendigos Nasdaq mastigam

mais cenas de mendigos, nas esquinas 
do ciberespaço em busca de miragens

(sacos pretos, azuis, coloridos).

É um vírus perverso, delicada

chacina, é um falso Gauguin, o celular

de um Baudelaire apressado tocando

na lama, um vaso de glicínias e camélias

metralhadas, é o mendigo queimado vivo

numa queima de arquivo

no Vale do Silício.

É um broker na Deep Web explodindo

a própria cabeça, uma ex-top model

dormindo na porta de um banco

em Barcelona, injetando

valsas vienenses nas veias.

É um estio com estilo,

antimatéria do não-sentido,

é um after party fatal, muralha de imagens

com milhares de vídeos idênticos,

um pôr do sol exuberante

(cheirado, uma carreira brilhante)

atropelado por um Hyundai Veloster.

Numa poça de agora estagnado

Eutomia, Recife, 26(1): 285 - 291, Dez. 2020 
a lua anula a luz do céu veloz.

A mendiga olha: um arco-íris se forma

na branca saliva de uma teia.

Praias patenteadas pela China, ar

a um real, rajada de hashtags na

noite, carvão do crepúsculo.

Hackers mendigos de terno preto Hugo

Boss puído, mijo, detritos, cratera,

a careca luzidia de Dr. Show,

traficante de maresia, cabeça pensa

num sofá de pedra, trincado

busto de manequim na sala VIP

do viaduto do verão

diante de um imenso grafitti

de "A Grande Onda", de Hokusai, projetado

no paliteiro da metrópole.

E ela cai, exangue, em câmera lenta, offshore.

Zap, zás, zoom, anti-Zeus, ratazanas Dior, pipocos de AR-15, mendigos fogem

de uma freak wave

de paparazzis italianos. Tulipa

chapada de Propofol

Eutomia, Recife, 26(1): 285 - 291, Dez. 2020 
lendo Caminho Suave pela Vereda Versace.

Usuários de crack com cachimbos privê,

biquinhos Gucci, os lábios leporinos

do Senhor Mercado, o matador de aluguel indiano

na boca de rango,

(o rosto limpo como uma enfermaria suiça).

Céu da cidade crua, fantasmas de milicianos,

brisa de commodities, rios cimentados

ou pior: céu fora do ar, noite

em pleno dia, em transe,

fumaça da Amazônia,

névoas de traças,

borboletas digitais de palavras

sem carne, sem viço, sem vida,

minuciosa e impiedosamente

estraçalhadas. 
Janela indiscreta

Em algum lugar perto deste hotel

alguém desafina uma Aquarela Brasileira no saxofone.

Longe, a espinha das serras azuis.

Um avião decola de São José dos Pinhais

rumo a Londres ou Londrina,

cruza o céu cinza da cidade grande.

Velha araucária espremida

entre prédios espelhados.

$\mathrm{Na} T \mathrm{~V}$, mais uma delação premiada.

Pessoas trabalhando ou nos celulares

em cada uma dessas janelas, abelhas.

Luzes se acendem, luzes se apagam.

A tarde cai fria e depressa.

Triste carne, triste Curitiba. 
Insular

A vila dorme solitária sob a chuva,

imenso cão cinza sobre os

sonhos de areia que o mar apaga.

A mente: esfarrapada

bandeira pirata.

Cego, o coração (compêndio

de velhos silêncios) caminha

no pátio deserto da noite,

pelas explosões da orla.

Em transe, o céu afaga

o que o mar escuro afoga:

letras em câmera lenta.

É a língua que naufraga

Em busca de uma voz

fosse uma trilha

no luto

da luz

as ondas congeladas

da minha fala

erigem uma ilha. 


\section{Tritina: sumi-ê}

Diante da paisagem o monge meditava há um dia.

Percebeu que o vento sul das montanhas

soprava mais forte, em direção às outras ilhas.

Confinado no templo, só pensava em arquipélagos, ilhas perdidas, guardadas no céu da retina, numa fresta de dia ou vistas, como de um drone, do alto das montanhas.

A névoa era uma imensa rede de pesca sobre as montanhas.

Aos poucos, montanhas eram de novo montanhas. Ilhas, ilhas.

Então lembrou o que o mestre, aqui mesmo, disse um dia:

"Um dia essas montanhas serão ilhas".

\footnotetext{
' Rodrigo Garcia Lopes é de Londrina, PR 1965, poeta, romancista, tradutor, compositor e jornalista.
} 